特別寄稿

\title{
日本情報地質学会に期待する
}

\author{
岩松 暉 ${ }^{1)}$
}

\section{Expectations for the Japan Society of Geoinformatics}

\author{
Akira IWAMATSU ${ }^{1)}$
}

\section{1. はじめに}

学会の功績賞とは, その学問分野で卓越した業績に対し て与えられるものだ。いわばその学会のスタープレイヤー に授与されるべきである。私は応用地質学に軸足を置き， 情報地質学の周辺部にいたアウトサイダーであり，応援団 を自認していた。それ故，辞退申し上げたのだが，どうし てもということで, やむなく頂戴した，恐縮の限りである. 記念講演では前半部で若干歴史を振り返ったが, 老人の 思い出話は見苦しい. また後半部は時間不足のため舌足ら ずで終わってしまった。 その反省の上に，この小文では， 講演後半部に述べた今後への期待あるいはお願いの部分 について，割愛した項目を補足しつつ記すこととする.

\section{2. 今後の社会}

現在, 世界はコロナウイルスパンデミックの最中にあ る. 2021 年 8 月現在，世界で 2 億人以上が感染し 430 万人 が死亡したという。実に世界大戦に匹敵する惨禍である。 パンデミックは同時に経済をも大きく破壊する。厳しい 感染症を生き抜いた人たちを，飢えで死なすわけにはい かない、ポスト・コロナ時代は, 格差社会ではなく, 否 応なく福祉社会を構想することが迫られる．弱肉強食の強 欲資本主義でもなく，20世紀型階級闘争でもなく，多様 性を認め合い, 自然とも, そしてウイルスとも折り合いを つけながら, 地方分散型の持続可能な社会を築いて行かな ければならないと思う。コロナ禍の中, SDGs (Sustainable Development Goals）がわが国でも多少スポットが当たり始 めたのは，その兆しかも知れない。国連で採択されたのは 2015年のことだから，ずいぶん遅まきだが.

しかし，政治・経済・社会を展望することは，私には荷 が重すぎる。学術にしぼりたい，そもそも展望論は，こう したエポックメーキングな大事件の後や時代の節目に登 場する，近年では，ミレニアム前後や東日本大震災後に盛 んだった。

ミレニアムの頃, 私は日本学術会議 (Science Council of Japan, 略称SCJ）の会員だった。会員選出は学会代表によ
る選挙の時代，たまたま日本情報地質学会会長職にあっ たため，選ばれたのだろう，SCJでは 21 世紀の展望を世 に示すべく準備を進めていた（2002年『日本の計画 Japan Perspective一学術により駆動される情報循環社会へ一』と して刊行; 第1図)。そのために各種委員会で議論を積み 重ねる方式を採っていた。私も学術の在り方常置委員会お よび科学論のパラダイム転換分科会の末席を污していた ので, 多少関わった。

総論は『日本の計画』として出版されたが, 各種委員 会の提言や報告も個々に公表されている。私が関わった ものには, 日本学術の質的向上への提言 (日本学術会議, 2002b), 新しい学術の大系一社会のための学術と文理の 融合一（日本学術会議, 2003a）および人間と社会のための 新しい学術体系 (日本学術会議, 2003b) がある。最後の「新

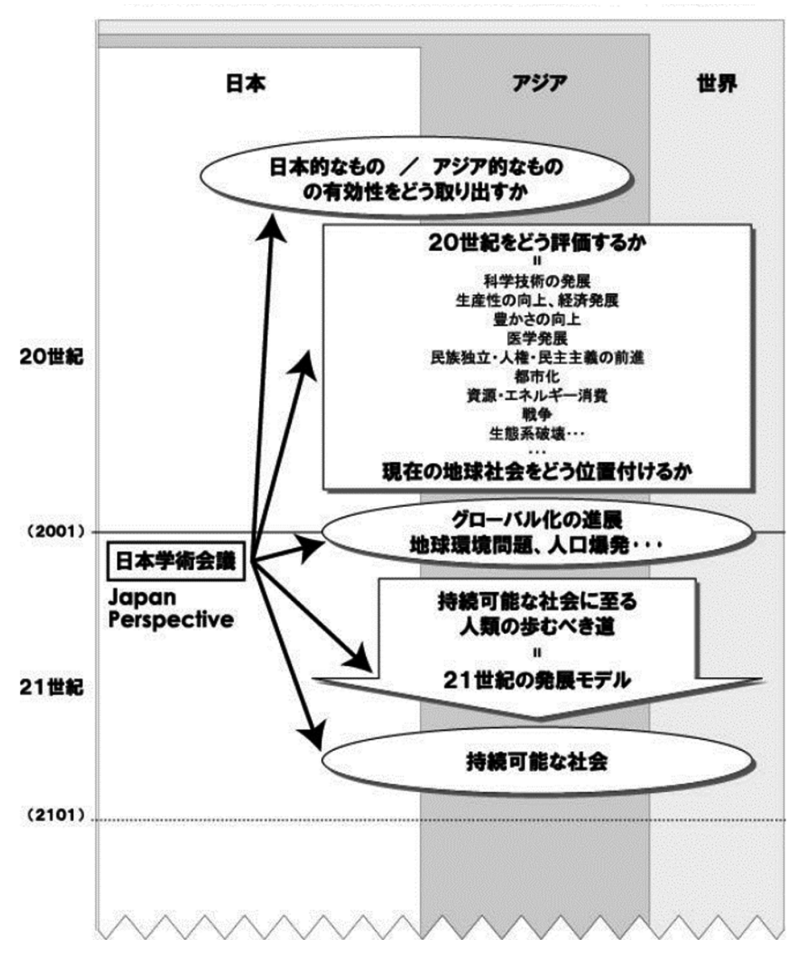

第 1 図「日本の計画」検討スコープ（日本学術会議，2002a） 
しい学術体系」には各論として「地球環境時代における地 質科学一資源中心の体系から環境中心の体系へ一」なる 各論を掲載した（岩松，2003）。

同し頃, 国際科学会議 (International Council for Science, 1989年まではInternational Council of Scientific Unions, 略称 はそのまま ICSU) 湖注〉と UNESCOが1999年, ミレニアム を目前にしてブダペストで世界科学会議World Conference on Scienceを開催，ブダペスト宣言を発表した。

すなわち, 20 世紀型の知識のための科学 science for knowledge に加え, 平和のための科学 science for peace ・開 発のための科学 science for development・社会における, 社 会のための科学 science in society, science for society とい う新しい責務 commitmentが加えられたのである. 当時, ICSU 会長は吉川弘之SCJ会長が兼務していたから，この 宣言にはSCJの意向も色濃く反映している。

\section{3. 行き詰まり問題と社会のための学術}

SCJ PICSU は, 当時の社会的課題を「行き詰まり問題」 と捉えていた，功古代文明が人口増加に伴う環境破壞 （人口圧）によって崩壊した時, 必ず別な地域で新たな文 明が勃興した。

時代は下って帝国主義の時代, 自国市場の狭隘さを克服 するために領土拡張に走る，植民地主義である．しかし， 更地のフロンティアはなくなり, 第一の行き詰まり,つま り地理的制約に突き当たった。

それを解決するために植民地再分割に突き進む。界大 戦である、生まれたばかりの飛行機が直ちに戦争に応用さ れたように，20世紀前半までは軍事目的に科学技術が動 員された。中山茂 (2003) はこれを第1のパラダイム,「軍 事的跛行の科学技術」と呼んでいる。しかし，二度にわた る世界大戦でも第一の行き詰まりは解決できなかった。

以後は自国に抢ける生産性を高めるしか方法がない，20 世紀後半は第 2 のパラダイム,「市場経済のための科学技 術」に莫大な投資が行われ，これによって科学技術は爆発 的に発展した。 その結果, 先進国では豊かで快適な社会を 実現し, ライフスタイルと価值観を大きく変化させた

一方, エネルギーと資源の浪費は地球環境を破壊し, 人 類生存の危機さえ叫ばれるような事態を招来した。また, 人口爆発や格差も深刻である。 世紀末にいたって第二の行 き詰まりに直面したのである。第一の行き詰まり問題は地 球の空間的有限性であったが, 今度は資源と環境の有限性 であった。

こうした人類史的課題としての「行き詰まり問題」を解 決し，持続可能な社会を実現するために，学術は何をなす べきなのだろうか、今や第3のパラダイム、「地球環境保

〈注〉2018年6月, ICSUは国際社会科学評議会 ISSC (International Social Science Council) と合併して国際学術会議 ISC (International Science Council, 略称ISC) になった. 国際アカデ ミーも文理融合になったのである。
全の科学技術」が求められる時代になったのである.

伝統的ディシプリン科学は, 認識と実践を切り離すこと によって，また研究対象を自ら狭め深く追究することに よって, 目覚ましい自立的自己充足的発展を遂げてきた。 科学のための科学 Science for Science だったのである. 結 果として, 学術の成果を社会に適用し, 逆にその経験を学 術にフィードバックする仕組みにそしかった，己のディシ プリンの中での最適解を追究するのみで，そのもたらす負 の効果や社会的影響には無頓着だった。フロン問題や環境 ホルモンなどが好例であろう。個別領域の研究を俯瞰する 「俯瞰型研究」が必要である.

今や一国の科学技術水準がその国の経済力を規定すると 言われるほど科学技術の社会的政治的影響力は強まってき た。こうした社会と学術との新しい関係の発生とその深ま りという現代の特徴を前にして, 学術は軌道修正を要請さ れていると言えよう.

われわれは再び本来の姿に立ち戻り, 知識の生産と利 用との関係の再構築を通じて, 人間と社会のための学術 Science for Society, いわば社会に埋め込まれた学術の確立 を目指さなければならない，新しい学術の体系,「統合シ ステムの科学と技術」が必要である. 当然のことながら, 研究者は広い視野と見識が要求される. 文理の融合さえ求 められているのではないだろうか.

さらに, 人間社会の持続可能性には, 物質・エネルギー 循環と情報循環が同時かつ調和的に実現されることが不可 欠である，象牙の塔に閉じこもることなく，社会との双方 向の情報発信・連携が求められる。最近では, 科学を職業 研究者の専有物から解き放ち, 市民との共創型研究を行う シチズンサイエンス Citizen Science も登場しつつある.

「社会のための学術あるいは科学」というと, とくに大 学人の中には嫌悪感を示す人がいる。科学は内在的な要因 によって発展するものであって, 何々のためといった目的 学ではないというものだ，要するに科学は科学者の知的 好奇心に基づく探究によって発展してきたという curiositydriven説である。これには厳しい批判もある.

清水幾太郎 (1972) はいう。「研究というものは, 自ら 設けた問題に答えようとする行為にほかならないが, 研究 者が少なく, 学会や機関誌の存在しない時期には, 問題は, 研究者が自ら設けるまでもなく, 現実によって設けられる のが普通であった。......ところが，科学抢よび科学者の発 展が行われると, 問題は現実から切り取られた封鎖的な世 界の内部で立てられる。皇れは野性的なものであることを やめて，人工的なものになる。問題それ自身が，その科学 の範疇や約束によって最初から規定されている.」(『倫理 学ノート』より)

確かに近年のようにアメとムチで業績主義を㮼られる と, 自らタコッボに閉じこもり視野を狭め, 同工異曲の論 文を大量生産する事態が蔓延した。清水（1972）の憂いを 誇張戯画化したような時代が出莱しているのだ。こうした 
人たちこそ象牙の塔から一歩踏み出す必要があろう。

逆に，政府当局や産業界からは，生好い，国民の税金 が使われており，産業や国の発展さらには国防のため奉仕 するのは当然，との声も聞かれる。2001年，総合科学技 術会議 (Council for Science, Technology and Policy, 略称: CSTP) が, 総合科学技術・イノベーション会議（Council for Science, Technology and Innovation, 略称：CSTI）に改組 され，2020年には，ついに科学技術基本法が科学技術· イノベーション基本法に変更された。 イノベーションを経 済再生の原動力と位置づけ，科学技術を総動員する出口志 向を鮮明にしたのである。

従来, SCJ とCSTP とは自転車の前輪と後輪に例えられ, 共通の了解事項だったはずだ。つまり，SCJが大所高所か ら方向性を決め, CSTPが駆動力になるという図式である. これまでも財政誘導が行われてきたが，今やCSTIが直接 的に方向性を示す仕組みになった。実際，内閣府に科学技 術・イノベーション推進事務局が設置され, 実務面まで直 轄となる。しかし, SCJやICSUのいう「社会のための科学」 はそのようなものではない.

\section{Future Earth と地球科学}

2012年, ICSU と地球圈 - 生物圈国際協同研究計画 (International Geosphere-Biosphere Programme, 略称：IGBP) など4つの国際研究計画が主催して, ロンドンで, Planet Under Pressure 会議が開催された。今まで分野別に取り組 んできた地球環境変動研究を統合することが審議され，持 続可能な地球社会の実現をめざす地球環境研究の国際的 な研究プラットフォームとして Future Earthが創設された (ICSU, 2013).

その基本理念は, これからの地球環境変動研究は超学際 研究 trans-disciplinaryであって, 利害関係者 stakeholders と 科学者が研究プロジェクトを co-design（協働企画）し，知 識を co-produce (協働生産)し, 結果をco-deliver (社会実装) するという枠組みだ，というものである(第2図).

従来の枠組みと異なる点は，自然科学中心だったものを 文理融合で進めるという点と，政策担当者や利害関係者も 立案に参加するという点であろう。

このロンドン会議で脚光を浴びた言葉がAnthropocene （人新世, 人類新世）という地質学的な概念である (Crutzen and Stoemer, 2000; Crutzen, 2002). 人類が地球に与える負 荷が大きくなりすぎ，不可逆的な変化が起きて人類が地球 環境を変えた新しい地質時代という意味らしい.日本でも SCJにフューチャー・アースの推進に関する委員会が設置 され，活動が始まっている。

完新世が終わり，人新世に入ったかどうかは議論の分か れるところだろうが，地質学的概念が主軸に置かれている のに, 地球科学者, とくに地質学者が無関心でいて良いわ けがない

そもそも地質学は地球環境と深く関わってきた。「21世

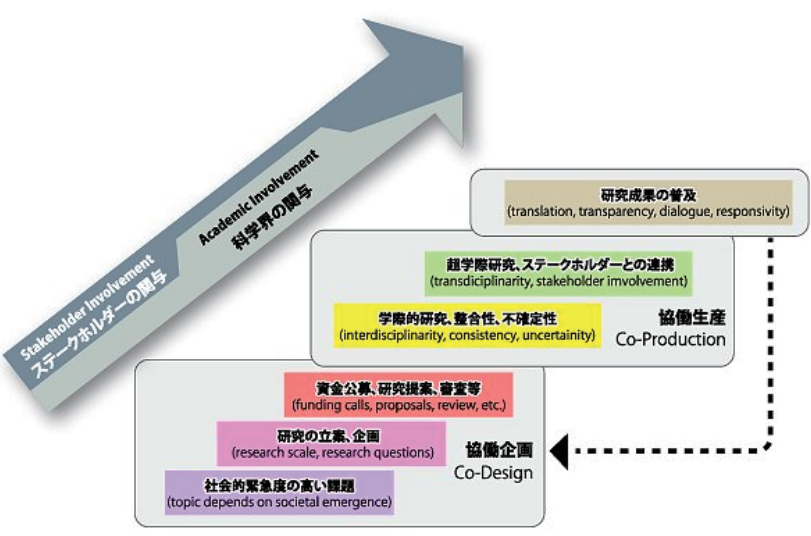

第2図 Future Earthの概念（文部科学省訳，2013）

紀の持続的発展に向けたメッセージ」と銘打った環境白書 平成11年版（環境庁，1999）には，20世紀は自然の収奪 と破壊が行われた「破壊の世紀」だったとある。世紀前半 は自然の収奪（資源開発）であり，後半は自然の破壊（乱 開発)であったという。

資源とエネルギーがあり，インフラを整備してきたから こそ，これだけの人口を養い豊かで快適な長寿社会を実現 できたのだら，いささか乱暴な総括ではある。しかし， 確かに地質学が前半では主役 (資源地質学), 後半では片 棒担ぎ (土木地質学) として破壊に果たした役割が大きかっ たことも事実である

総懺悔をするのは不毛だが，新しい持続可能な社会へ向 けて何をなすべきか，立ち止まって熟慮することは必要で あろう。

\section{5.「災後」のジオサイエンス}

折しも2011年，東日本大震災が発生し，世界を震撼さ せた。この大震災では，しばしば「想定外」という語が使 われ流行語になった。しかし，地質学者達は津波堆積物の 研究から，貞観地震津波（869）の規模を知っており，想 定外ではなく，数百年〜千年に一度の災害が，再び発生し たと受け止めた。俄然，地質学の重要性が再認識され，そ の後の地震火山観測研究計画や大規模地震防災 - 減災対策 大綱等に「地質」の文言が入った。

地質が注目されるようになったことは喜ばしい.しかし, 貞観津波クラスの津波があると思っていたなどと事後解説 してもらってもありがたくないし，この活断層は明日動く かも知れないし，1000年後かも知れない，などと言われ ても対応しようがない。「人間の寿命のオーダーでの時間 尺度」で予知予測ができなければ，解釈・解説の学問と謗 られてもやむを得ない，災害年表づくり，危険個所抽出た けで満足されても困る.

震災後 5 周年に，私は「贸後」のジオサイエンスなる小 文を書いた（岩松，2016）。骨子は次のとおりである。

近現代の歴史区分として，「戦後」という語がよく使わ 
れる。確かに明治憲法体制と現行憲法体制とを画する大事 な区切りだ。しかし，その戦後もここで大きな転換点に来 ている。高度成長, 右肩上がりの時代から, 低成長・人口 減少の時代がやってきた。 自然は征服すべき対象と考えて いた時代から, 自然と折り合いを付けながら, 身の丈に合っ た生活をしていく時代になった。原発事故に象徴されるよ うなエネルギー多消費型文明にも反省が迫られている。

社会に大きな影響を与えた自然災害としては1775年の リスボン地震を挙げることができる、そう単純ではないが, 西欧社会が教会のくびきを解き放ち, 啓蒙主義へ大きく踏 み出すきっかけになったとも言われている。わが国に打け る「災後」も大きな文明の転換点なのだと思う。

それでは，東日本大震災が突きつけたものにどう応える か. 私は, 従来の狭いディシプリンを超えたインテグレー 卜したジオサイエンスが求められていると考えている。

地震に例を取ろう。地震学者は地震波動を観測するか弾 性波動論に基づき理論的に追及する，地質学者は活断層の 露頭を調へ，平均変位速度や再来周期を解明する，2極分 解である。しかし, 地震は地球深部に㧍ける断層運動, つ まり岩石の破壞現象なのだから，単に破壊の結果発生した 波動を観測するだけではなく, 塑性論も含む岩石力学・構 造岩石学・岩石化学的な, さらには流体力学的な見方が求 められる。幸い観測船「ちきゅう」により地球深部の物質 が入手できるようになり，物質科学的研究が可能になった 両者の協力協働が求められる. 当然, 教育面での裏付けも 必然的に求められる。

\section{Society 5.0 と Digital Transformation (DX)}

東日本大震災から 10 年経った現在, われわれの置かれ ている状況はどうだろうか．近未来には何が待っているの だろうか. わが国では英語やカタカナで表現すると, 何と なくあこがれを誘発すると思われているのか，㧍役所の文 書にも汇濫している.

Society 5.0 は第 5 期科学技術基本計画が提唱したキャッ チコピーである（総合科学技術・イノベーション会議, 2016)。サイバー空間 (仮想空間) とフィジカル空間 (現実 空間）を高度に融合させたシステムにより, 経済発展と社 会的課題の解決を両立する, 新たな人間中心の未来社会を いうのだそうだ。もちろん，狩猟社会 (Society 1.0), 農耕 社会 (Society 2.0), 工業社会 (Society 3.0), 情報社会 (Society 4.0)に続くという意味だ.

内閣府のホームページでは次のように解説している（内 閣府, 2016 ; 第3図参照).

「IoT (Internet of Things) で全ての人とモノがつながり, 様々な知識や情報が共有され，今までにない新たな価值を 生み出すことで,これらの課題や困難を克服します。また, 人工知能 $(\mathrm{AI})$ により, 必要な情報が必要な時に提供され るようになり，ロボットや自動走行車などの技術で，少子 高齢化，地方の過踈化，貧富の格差などの課題が克服され

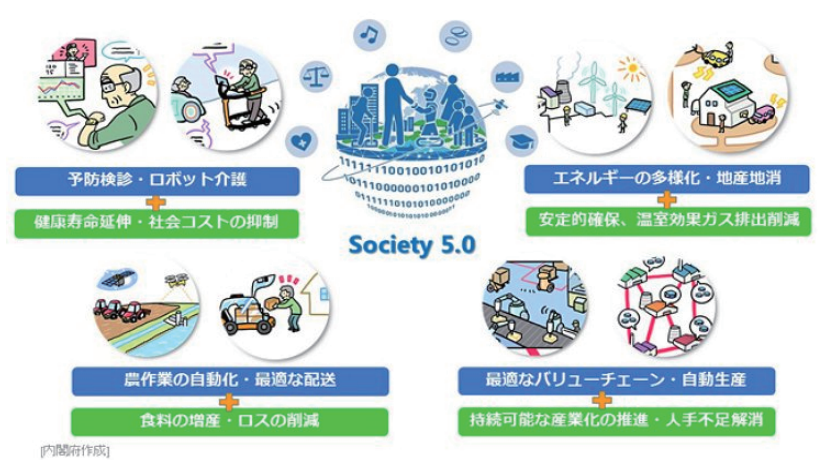

第3図 Society 5.0 に打ける経済と社会 (内閣府，2016）

ます、社会の変革 (イノベーション)を通じて，これまで の閉塞感を打破し，希望の持てる社会，世代を超えて互い に尊重しあえる社会，一人一人が快適で活躍できる社会と なります.」

それから 5 年経過したが, バラ色の未来社会へ半歩でも 近づいたであろうか. 目玉のスマートシティーもまだ登場 していないし，そもそもロボットで少子高齢化・過疎化· 格差などが解消されるとは思えない，ロボット掃除機です ら，自宅にあるのは比較的裕福な家庭であろう。コロナ禍 のお荃で, 半強制的にテレワークやリモート講義が実現し たこと，ビッグデータ解析で盛り場の人出が計測できるよ うになったことぐらいが成果と言えば成果であろうか.

次はDigital Transformation (DX) である。もともとはス ウェーデンの Stolterman and Fors (2004) が「IT の浸透が人々 の生活をあらゆる面でより良い方向に変化させること」と 定義したものらしいが，わが国では経済産業ガイドライン （経済産業省，2018）が次のように定義した。

「企業がビジネス環境の激しい変化に対応し，データと デジタル技術を活用して，顧客や社会のニーズを基に，製 品やサービス，ビジネスモデルを変革するとともに，業務 そのものや, 組織, プロセス, 企業文化·風土を変革し, 競争上の優位性を確立すること」

ただし，単なるデジタル化の推進と受け止める向きもあ るが, ビジネスモデルの変革まで含まれることに留意が必 要である。こちらのほうは, 推進している経済産業省省自 身が「2025年の崖」と言っているくらいだからかなり厳し い. 現在わが国の多くの企業が業務に使っているIT シス テムがレガシーシステム化 (老朽化・肥大化・複雑化・ブ ラックボックス化）していて，更新がままならないからで ある、設備投資に莫大な費用がかかることもあるが，往時 システム構築に関わった技術者が世代交代し, 現役にとっ ては,まさにブラックボックスとなっているからでもある. 昨今，金融や交通・電力などあらゆる分野でシステム障害 によるトラブル発生が報じられているのも，これが原因の ようだ。

システムだけでなく，そもそも日本のIT産業が，かつ ての栄光の座から滑り落ち, 欧米や中国の後塵を扯してい 
る。デジタル庁が創設されれば，全て解決されるわけでは ない.とは言え, IoT, AI, ビッグデータ, 5G・6G（ビヨ ンド $5 \mathrm{G})$ などが，身近な存在になることは必然ではある。

\section{CIM と地質リスクマネジメント}

未来社会を論じるのは，どうしても抽象的になりが ちである。その点，現業官庁である国土交通省の描く i-Constractionは具体的た（国土交通省，2016）。ICTの全 面的な活用（ICT土工）により，建設生産システム全体の 生産性向上を図り，もって魅力ある建設現場を目指す，と している。また，計画・調査・設計・施工・維持・管理といっ た建設生産プロセス全体のシームレス化も狙っている。そ れが BIM/CIM (Building/ Construction Information Modeling, Management）である(第4図)。三次元の形状情報（三次 元モデル）に物性などの属性情報も付加したBIM/CIM モ デルを建設生産の全プロセスで共有しようとするもので, 2020 年にはガイドラインが出され，2023年には全面適用 するという（国土交通省，2020a）。現在は地質調査業界で も対応に大わらわであろう。

その後，これに地質地盤リスクマネジメントが加わって きた，福岡市における地下鉄建設に関わる道路陥没事故が 発生したのを契機としている。地質情報の不確実性あるい は複雑性（推定誤差・ばらつき）が施工側に正しく伝わっ ていなかったからである。2020年には土木事業における 地質・地盤リスクマネジメントのガイドラインが出された （国土交通省，2020b）。建設生産の全プロセスで共有され るためには，難しい地質学用語の羅列ではなく，見える化 (見せる化) が重要になるから，ここでも三次元モデルが 多用されるであろう。

注意すべき点がある。モデル化しにくい事項が捨象され， リスクがなかったことにされかねないことだ。さらにモデ ル化はコンピュータに強い職員任せに，やがてはソフト任 せになり,ブラックボックス化する可能性がある。 心したい.

なお，このガイドラインには看過できない点が指摘さ れていた，地質情報の不確実性云々の前に，地質技術者 のフィールド調査能力が著しく低下しており，そのミス ジャッジに起因する人為的要因がリスクの 8 割も占めると

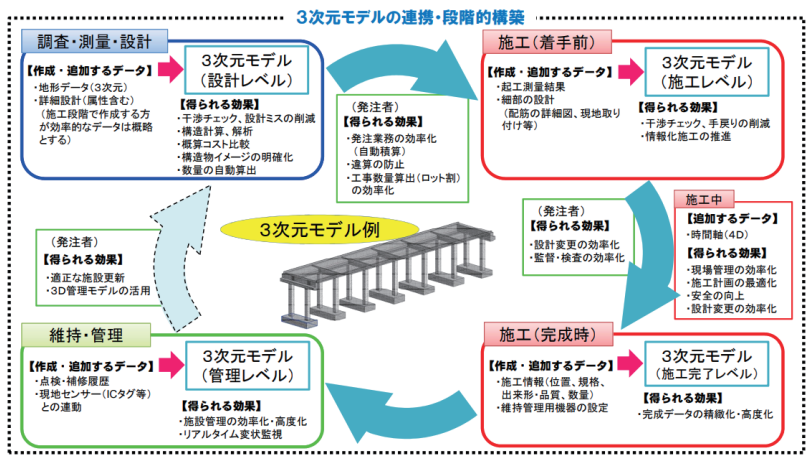

第4図 CIM の概要（国土交通省，2020a）
の指摘だ。大学教育が反省を迫られていると解すべきであ ろう.

\section{8. 日本情報地質学会に期待する}

大所高所の未来論からお役所の近未来論まで簡単にス ケッチした。来たるべき未来社会において情報地質学に何 を期待しているのか，言外に何を言いたいのか読み取りい ただけたものと思う

もともと情報地質学は学際的学問として誕生した。その 点，明治の昔から存在していた古典的分野とは異なる。大 学の地質学教育で, 必修基礎科目として学生に教授される 岩石・鉱物・化石の鑑定などは，当時，鉱山会社や石油会 社に就職するために不可欠の職業教育だったのである。清 水（1972）の指摘通り，問題は実社会から与えられていた のだ。

情報地質学は生まれて 30 年，まだ野性的であるはずで ある、社会のための科学と言っても違和感を持つ人はいな いであろう。社会が求めている点を例示してみたい。

先ずはSCJのいう持続可能な社会を実現するというテー マを常に念頭に置き，何らかの形でコミットして欲しい. 例えばスマートシティーなどの立案に，物流網の構築や宅 地の配置などGIS は深く関わるが，情報地質分野の方は地 域創生などには関心がないようだ。20世紀，大都市近郊 の丘陵地に大規模団地を造成した結果，斜面災害が激発す るようになった，かつて地質学者がこうした事案に無関心 だったツケである.未必の故意と誹られてもやむを得ない.

そもそも地形情報と地質情報は密接不可分であり，地理 学と地質学の協力協働は欠かせない。先にインテグレート したジオサイエンスと書いた。両者ともジオサイエンスな のだ。防災面での貢献も求められているから，もっとこの 方面へも進出して欲しい.

もちろん，情報地質学は地球情報学でもある。ローカル なことばかりでなく, 水・大気・海洋を含むグローバルな 地球環境問題にも手を広げて欲しいと思う。

気候変動問題も深刻だが，水問題も劣らず深刻である. 第二次大戦は石油資源をめぐって戦われた。次の大戦は水 資源の争奪戦との不気味な予言もある。イスラエルがゴラ ン高原（旧称シリア高原）を占領し続け，入植まで進めて いるのは，重要な水源地だからだ。世界の穀倉アメリカで は，本来は砂漠の地に有限の地質地下水を使って刹那的な 灌溉農業を行っており，近い将来深刻な事態となろう。78 億の人口を養うために, 水は喫緊の課題である。AIやビッ グデータを活用したアプローチはないものだろうか.

日本情報地質学会が先駆的に推進してきた論理地質学 は，点と線の情報から三次元地質体を客観的自動的に再構 成することを目指した画期的なものだった，地質学の根本 原理に関わることではあるが，やはり地質図学の範ちゅう である、コンピュータも2進法の四則演算から始まったの だから，当然必要なステップだ。しかし，そろそろ時間軸 
を取り入れ，地質構造発達史にチャレンジしても良い頃で はなからうか.

応用地質学の立場から言えば, CIMに力を貸して欲し い. CIM と言えば当然三次元モデルだが，どうも測量技師 の独壇場の感があるようだ。ドローンを飛ばしてLiDAR で測量し，それを市販ソフトで処理して成果品とする。ま さにルーチン作業である，本当はそれからが本番である。 出来上がった詳細な地形図を読み解く画像診断が一番重要 なのだ，熟達した地質技師なら，地すべりや崩壊，活断層 などを抽出することができる。

地形図の読図は地理学では不可欠だが, 本来, 地質学で も必須のはずなのに, 大学の縦割りのためか, 地質学では 等閑視されている，真に読図のできる人は少なく，名人芸 とも称される. AIを駆使してこの名人芸を再現できない ものだろうか。 また，段丘面区分など地形学図の自動作図 法も開発して欲しいものた。.

ただし，これでは単に地形情報だけである，三次元とい うからには地質情報が不可欠である。当然, フィールドエ ビデンスが一番重要だが, ドローン測量に比べたら手間暇 がかかる。 その上昨今の人材不足やレベル低下のため, 残 念ながら簡略に済まされるケースが多い，地質リスクが発 生する原因ともなっている.

一方, 物理探查の進歩も望まれる. 可視光線で見るのも, 弾性波で見るのも波長が違うだけで, 電磁波で見ているの に変わりはない，原理的なブレークスルーも必要だが，ソ フト的な革新も求められているのではなからうか.

また，地質地盤リスクの見える化に，ご協力をいただき たい.これからはビッグデータの時代である.地質情報ビッ グデータの斬新な活用と新分野の開拓を望みたい.

最後に, 2025 年には大学入試に情報科目が入ってくる という.かつて雲仙普賢岳災害の際, 土石流シミュレーショ ンソフトを使用した火砕流シミュレーションを見たことが ある、流体サポートとガス・サポートでは搬送メカニズム が根本的に異なる。第一, 土石流ソフトには温度のパラメー ターがない.これは極端な例だが, 近頃の学生の中には, あるいは研究者の中ですら, 外国製市販シミュレーション ソフトや統計解析ソフトをブラックボックスとして使用し ている人がまま見受けられる。また誤差論をわきまえない 細かな議論も散見する。大学に打ける情報教育・数学教育 の抜本的刷新にご尽力いただきたい。もちろん，情報教育 の強化は，フィールド教育の軽視を意味しない。助の上の 水練化につながらないことを願う。

以上思いついたことをいくつか列挙した，久落した事項 も多々あろう。時には日常の研究の手を休め, 壮大な展望 を語り合うのも良いのではないだろうか. 日本情報地質学 会が飛躍的に発展することを祈念して擱筆とする.

\section{文献}

Crutzen, P. J. and Stoemer, E. F. (2000) The "Anthropocene". Global Change Newsletter, vol. 41, p. 17-18.

h t t p : / / w w w.ig b p . ne t/ d o w n load / 18.31 6f18321323470177580001401/1376383088452/NL41.pdf

Crutzen, P. J. (2002) Geology of mankind. Nature, vol. 415, no. 23. https://doi.org/10.1038/415023a

International Council for Science(ICSU) (2013) Future Earth: Draft initial design report. $121 \mathrm{p}$.

https://www.researchgate.net/publication/256542719_ FutureEarth_Draft_initial_design_report.

岩松暉（2003）地球環境時代における地質科学一資源中 心の体系から環境中心の体系へ一. 日本学術会議「人 間と社会のための新しい学術体系」, pp. 31-39.

http://www.scj.go.jp/ja/info/kohyo/pdf/kohyo-18-t995-45.pdf 岩松 暉 (2016)「災後」のジオサイエンス. 学術の動向,

vol. 21, no. 4, pp. 78-83. https://www.jstage.jst.go.jp/article/ tits/21/4/21_4_78/_pdf/-char/ja

環境庁 (1999) 環境白書平成 11 年版. 大蔵省印刷局, 513 p. 経済産業省 (2018) デジタルトランスフォーメーションを 推進するためのガイドライン (DX 推進ガイドライン) Ver. 1.0. 経済産業省, 9 p. https://www.meti.go.jp/pre ss/2018/12/20181212004/20181212004-1.pdf

国土交通省 (2016) i-Construction～建設現場の生産性革命 ～. i-Construction 委員会報告, 29 p. https://www.mlit.go.jp/common/001127288.pdf

国土交通省（2020a）CIM 導入ガイドライン(案) 共通編. 本文 : 8 p., 参考資料 : 120 p.

https://www.mlit.go.jp/tec/content/001334802.pdf

国土交通省（2020b）土木事業における地質・地盤リスク マネジメントのガイドライン一関係者が ONE-TEAM で リスクに対応するために一。国土交通省大臣官房技術 調査課・国立研究開発法人土木研究所・土木事業におけ る地質地盤リスクマネジメント検討委員会, 69 p.

https://www.pwri.go.jp/jpn/research/saisentan/tishitsu-jiban/ pdf/georisk-guideline2020.pdf

文部科学省（2013）持続的な地球環境のための研究の進め 方について, 中間とりまとめ(論点整理). 文部科学省, 科学技術・学術審議会, 研究計画・評価分科会, 環境工 ネルギー科学技術委員会, 持続可能な地球環境研究に関 する検討作業部会, $34 \mathrm{p}$.

https://www.mext.go.jp/b_menu/shingi/gijyutu/gijyutu2/068/ houkoku/_icsFiles/afieldfile/2014/02/27/1341083_01.pdf

内閣府 (2016) Society 5.0.

https://www8.cao.go.jp/cstp/society5_0/index.html 中山茂 (2003) 近代科学技術史上の第 3 のパラダイム. 日本学 術会議「人間と社会のための新しい学術体系」, pp. 75-81. http://www.scj.go.jp/ja/info/kohyo/pdf/kohyo-18-t995-45.pdf 日本学術会議（2002a）日本の計画 Japan Perspective一学 
術により駆動される情報循環社会へ一。日本学術会議, 48 p. http://www.scj.go.jp/ja/info/kohyo/18pdf/1852.pdf

日本学術会議（2002b）日本学術の質的向上への提言. 日 本学術会議学術の在り方常置委員会, $104 \mathrm{p}$. http://www.scj.go.jp/ja/info/kohyo/18pdf/1854.pdf

日本学術会議 $(2003 \mathrm{a})$ 人間と社会のための新しい学術体系. 日本学術会議新しい学術体系委員会・学術の在り方常置 委員会・科学論のパラダイム転換分科会, $85 \mathrm{p}$. http://www.scj.go.jp/ja/info/kohyo/18pdf/1828.pdf

日本学術会議（2003b）新しい学術の大系一社会のための 学術と文理の融合一。日本学術会議新しい学術の大系 委員会, $181 \mathrm{p}$. http://www.scj.go.jp/ja/info/kohyo/18pdf/1829.pdf 清水幾太郎（1972）倫理学ノート。岩波書店, 327 p. 総合科学技術・イノベーション会議（2016）第 5 期科学技 術基本計画, 内閣府, $53 \mathrm{p}$. https://www8.cao.go.jp/cstp/kihonkeikaku/5honbun.pdf Stolterman, E. and Fors, A. C. (2004) Information technology and the good life. In : Kaplan B. et al. (eds) Information Systems Research, IFIP International Federation for Information Processing, vol. 143. Springer, Boston, MA., pp. 687-692. https://doi.org/10.1007/1-4020-8095-6_45

上記 URL は 2021 年 8 月 16 日に最終確認した. 